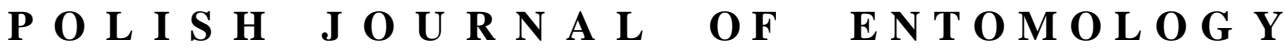

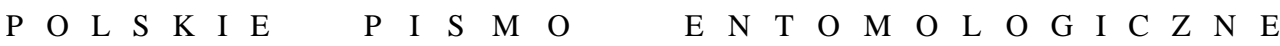

VOL. 87: 85-99

Lublin

31 March 2018

DOI: $10.2478 /$ pjen-2018-0007

\section{Repellency potential of some botanicals against the maize weevil, Sitophilus zeamais (MoTSCHULSKY, 1855) (Coleoptera: Curculionidae) in stored sorghum}

\author{
Mohammed Suleiman ${ }^{1,4^{*}}$, COSTANCia P. Rugumamu², \\ NASIRU D. IBRAHIM ${ }^{3}$ \\ ${ }^{1}$ Department of Zoology and Wildlife Conservation, University of Dar es Salaam, Tanzania \\ ${ }^{2}$ Department of Crop Sciences and Beekeeping Technology, University of Dar es Salaam, \\ Tanzania \\ ${ }^{3}$ Department of Crop Science, Usmanu Danfodiyo University, Sokoto, Nigeria \\ ${ }^{4}$ Department of Biology, Umaru Musa Yar'adua University, Katsina, Nigeria
}

\begin{abstract}
Repellency of Euphorbia balsamifera, Lawsonia inermis, Mitracarpus hirtus and Senna obtusifolia along with permethrin powder against Sitophilus zeamais was evaluated in the laboratory at $28-32^{\circ} \mathrm{C}$ and $60-75 \% \mathrm{RH}$. The botanicals were applied as powders, methanolic, ethanolic and aqueous extracts at the rate of 2.5, 5.0 and $10.0 \times 10^{4} \mathrm{ppm}$ per $20 \mathrm{~g}$ of sorghum grains, while the permethrin powder was applied at $0.056 \times 10^{4} \mathrm{ppm}$. Percentage repellency was recorded at 1, 6, 12 and 24 hours after exposure (HAE). All the botanicals were found to have a repellent effect against Sitopholus zeamais at all three concentrations. The highest $(82.22$ $\pm 2.22 \%$ ) repellency among the botanical powders was exhibited by $10.0 \times 10^{4} \mathrm{ppm}$ of Euphorbia balsamifera within 24 HAE. Methanolic leaf extracts were found to be more effective than the other formulations, causing total repellency against the weevils at $10.0 \times 10^{4} \mathrm{ppm}$ of all the botanicals, while the activities of the aqueous extracts were the least repellent $(41.37 \pm 7.39$ to $60.14 \pm 1.64 \%$ ) after 24 hours of exposure. The repellent activities of the botanicals decreased with increasing exposure periods for powders and aqueous extracts, and increased with increasing duration for methanolic and ethanolic extracts. The results showed that the botanicals were good repellents against Sitopholus zeamais and could serve as stored sorghum protectants against maize weevil infestation. Grains protected with these botanicals could be used as seeds for planting. Meanwhile, studies on the toxicity of these botanicals against higher animals are recommended.
\end{abstract}

KEY WORDS: Botanicals, Extracts, Powders, Repellency, Sitophilus zeamais, Sorghum grains.

\footnotetext{
* Corresponding author: mohammed.suleiman@umyu.edu.ng
} 


\section{INTRODUCTION}

Repellents of botanical origin are desirable chemicals as they offer protection with minimal impact on the ecosystem, and as they drive away the insect pests from the treated materials by stimulating olfactory or other receptors of insects (RAJASHEKAR et al. 2012). The repellency of plant material has been exploited for thousands of years by man, simply by hanging bruised plants in houses, a practice that is still in wide use throughout the developing countries (MAIA \& MORE 2011). Repellents of plant origin are considered safe in pest control, minimize pesticide residue, and ensure the safety of people, food and the environment (TALUKDR 2006). JAYANHI et al. (2014) explained that volatile odour components of plants play a pivotal role in host identification and acceptance by insects. Acceptable host-plant odours, in combination with their environmental cues, can be attractive to insects, whereas non-host odours can either repel insects or have no effect on their behaviour (KUHS et al. 2016). These odour cues can be exploited to alter how insects perceive their landscape (JAYANHI et al. 2014). GOVINDARJAN et al. (2011) reported that more than 1005 plant species possess insecticidal properties, 384 contain antifeedants, 297 repellents, and 27 possess growth inhibitors. ZOUBIRI \& BAALIUAMER (2014) reviewed the potential insecticidal properties of 230 plant species: 12 of them were reported to repel some insect pests. OBICO \& RAGRAGIO (2014) found seven plant species to be the most important ones used as insect repellents, including Leucaena leucocephala (LAM.) DE WILT, Gliricidia sepium (JACQ.) WALP., Eucalyptus sp., Gmelina arborea RoXB., Azadirachta indica A. JUSS. and Phyllodium pulchellum (L.) DESV. These species contain a number of bioactive compounds like terpenoids, alkaloids, glycosides, phenols, tannins and flavonoids in their leaves, stems, bark, seeds and oil (VERA et al. 2016).

In the tropics, several plant products have been employed in subsistence agriculture for the protection of stored grains against a number of storage insects, and their success rate has been encouraging (LALE 2006). Repellent actions of some plant materials against Sitophilus spp. infesting stored grains have recently been reported (MWANGANGI \& MUTISYA 2013, ANKUTSE 2014, ARYANI \& AUAMCHAROEN 2016).

SulEIMAN et al. (2012) revealed the repellency potentials of leaf powders of Euphorbia balsamifera AITON and Lawsonia inermis L. against Sitopholus zeamais (MOTSCHULSKY, 1855). The repellent action of some plant products might be due to the volatility of the pungent smell, which elicits a reversible reaction in insects (ASAWALAM \& EMOSAIRUE, 2006). However, information on the repellency actions of leaf powders and extracts of the plant species chosen for this study against $S$. zeamais is scanty. Therefore, this study was conducted to evaluate the repellency potential of leaf powders as well as methanolic, ethanolic and aqueous extracts of Euphorbia balsamifera, Lawsonia inermis, Mitracarpus hirtus (L.) DC. and Senna obtusifolia (L.) H.S.IRWIN \& BARNEBY against Sitopholus 
zeamais infesting sorghum grains in order to ascertain their protectant potential during the post-harvest period.

\section{MATERIALS AND METHODS}

\section{Rearing of the insects for the experiments}

Fifty pairs of Sitopholus zeamais were obtained from infested grain stores at Katsina Central Market, Nigeria, and then introduced into rearing bottles $(500 \mathrm{ml})$, each containing $250 \mathrm{~g}$ of disinfested sorghum grains. The bottles were covered with pieces of muslin cloth and kept in an incubator for oviposition at $30^{\circ} \mathrm{C}$ and $70 \%$ R.H. for 14 days, after which the parents were removed (GOFTISHU \& BELETE 2014). The bottles were maintained in the incubator under the same conditions until adult emergence. The seven-day-old progeny were sieved from the infested grains and used for the experiments.

\section{Preparation of the botanicals for the experiments}

Fresh leaves of Euphorbia balsamifera, Lawsonia inermis, Mitracarpus hirtus and Senna obtusifolia were collected from an uncultivated area around Umaru Musa Yar'adua University, Katsina (UMYUK), Nigeria. The leaves were rinsed with distilled water to remove any dust and unwanted particles. They were then shade-dried at room temperature for 14 days. The dried leaves were ground into powder using a laboratory blender (Model 8010ES) and sieved into fine powder using a laboratory sieve with an 80-micron mesh. The powders were kept separately in plastic bottles at room temperature (PARUGRUG \& ROXAS 2008).

One hundred grams of each of the plant powders was dissolved in $400 \mathrm{ml}$ of methanol, ethanol and distilled water in conical flasks. The mouths of the flasks were securely corked and kept in the laboratory at room temperature for 48 hours. The extracts were separated using muslin cloth and filtered with Whatman No.1 filter papers using a vacuum pump (Dymax 14) as described by KHALIQ et al. (2014). The filtrate was separately concentrated by evaporating excess solvents using a rotary evaporator with a rotary speed of 3 to $6 \mathrm{rpm}$ for 8 hours. When the contents had almost completely evaporated, aliquots were poured into evaporating dishes and placed in a water bath to evaporate the remaining/excess solvents. The resulting extracts were air-dried to remove traces of the solvent and were then stored in a refrigerator at $4{ }^{\circ} \mathrm{C}$ (ABOU-ELNAGA 2015) prior to use in the repellency tests. 


\section{Repellency Tests}

\section{Determination of repellent activities of botanical powders against Sitophilus zeamais}

The methods of REJTTHA et al. (2014) were employed for testing the repellency potentials of powdered Euphorbia balsamifera, Lawsonia inermis, Mitracarpus hirtus and Senna obtusifolia. An apparatus consisting of three plastic bottles (100 ml) connected by two plastic tubes $15 \mathrm{~cm}$ long and $1 \mathrm{~cm}$ in diameter at $180^{\circ}$ was designed for each treatment. The three plastic bottles were labelled A, B and C, with B as the central chamber. Twenty grams (20 g) of sorghum grains were placed in bottle A of each apparatus mixed with different concentrations of 2.5, 5.0 and $10.0 \times 10^{4} \mathrm{ppm}$ equivalent to $2.5,5.0$ and $10.0 \%$ weight per weight (w/w), respectively, of Euphorbia balsamifera leaf powder. The concentrations were chosen based on recommendations of DALES (1996) that dry powdered material should be added to a commodity at the rate of 1 to $5 \%(\mathrm{w} / \mathrm{w})$. Another $20 \mathrm{~g}$ of sorghum grains without any powder was placed in $\mathrm{C}-$ this served as a control. Ten adult Sitophilus zeamais obtained from the rearing phase of the experiment were introduced into bottle B. The same set-ups were made for each of Lawsonia inermis, Mitracarpus hirtus and Senna obtusifolia, while $0.056 \times 10^{4} \mathrm{ppm}$ (equivalent to $50 \mathrm{~g} / 90 \mathrm{~kg}$ ) of permethrin powder, as recommended by MUTAMBUKI \& NGATIA (2012) was added to another 20 $\mathrm{g}$ grains as a chemical check. All treatments and controls were replicated four times.

\section{Determination of repellent activities of botanical extracts against Sitophilus zeamais}

For the extract treatments, methanolic, ethanolic and aqueous crude extracts of each of the four botanicals were diluted to three different concentrations of $2.5,5.0$ and $10.0 \times 10^{4}$ $\operatorname{ppm}(2.5,5.0$, and $10.0 \% \mathrm{w} / \mathrm{v})$. The concentrations were made by diluting $0.5,1.0$ and $2.0 \mathrm{~g}$ of crude extracts of Euphorbia balsamifera, Lawsonia inermis, Mitracarpus hirtus and Senna obtusifolia in $20 \mathrm{ml}$ methanol, ethanol and distilled water to obtain 2.5, 5.0 and 10.0 x $10^{4} \mathrm{ppm}$, respectively. Two $\mathrm{ml}$ of each of the extracts was taken using a micropipette and added to $20 \mathrm{~g}$ of sorghum grains in bottle A. The grains were vigorously stirred using a glass rod to ensure proper mixing with the extracts and then air-dried for one hour. Another $20 \mathrm{~g}$ of grains without any botanical extract were placed in bottle $\mathrm{C}$ to serve as a control. The treatments were replicated four times in which ten adult Sitopholus zeamais were introduced to bottle $\mathrm{B}$, from where their direction of movement to either bottle $\mathrm{A}$ or $\mathrm{C}$ was observed at $28-32^{\circ} \mathrm{C}$ and $60-75 \%$ R.H.

In both powder and extract treatments, the number of weevils moving from bottle $\mathrm{B}$ to either bottle $\mathrm{A}$ or $\mathrm{C}$ was recorded at 1, 6, 12 and 24 hours after exposure. Percentage Repellency (PR) was calculated according to the methods of SAKUMA \& FUNKAMI (1985):

$$
\mathrm{PR}=1-\frac{\mathrm{NT}}{\mathrm{NT}+\mathrm{NC}} \times 100
$$


where:

$\mathrm{PR}=$ Percentage Repellency

$\mathrm{NT}=$ Number of insects in the chemical-treated test chamber

$\mathrm{NC}=$ Number of insects in the control test chamber

\section{Data analysis}

The data collected were analysed using GraphPad Prism (version 7.03). They were first tested for normality using the Shapiro-Wilk normality test. One-way ANOVA was used to test significant differences that existed between the percentage repellency of different concentrations of Euphorbia balsamifera, Lawsonia inermis, Mitracarpus hirtus and Senna obtusifolia and within the botanicals at individual concentrations against Sitophilus zeamais after every exposure period. Two-way ANOVA was also employed to test the level of significance in percentage repellencies among the botanicals at different concentrations. Bonferroni's multiple comparisons test was used to separate significantly different means at the $5 \%$ level of significance.

\section{RESULTS}

\section{Repellent activities of botanical powders against Sitophilus zeamais}

The percentage repellency of Euphorbia balsamifera powder ranged from $79.73 \pm 3.28$ to $83.09 \pm 1.17 \%$ at $2.5 \times 10^{4} \mathrm{ppm}$, from $81.01 \pm 2.32$ to $86.67 \pm 4.51 \%$ at $5.0 \times 10^{4} \mathrm{ppm}$ and from $82.22 \pm 2.22$ to $94.10 \pm 3.42 \%$ at $10 \times 10^{4} \mathrm{ppm}$ within $24 \mathrm{HAE}$ (Table 1).

Table 1 shows that leaf powders of Lawsonia inermis repelled adult Sitophilus zeamais to varying degrees after different exposure periods. The percentage repellency of the botanical powder from one to $24 \mathrm{HAE}$ ranged from $63.34 \pm 1.93$ to $80.42 \pm 7.08 \%$ at 2.5 x $10^{4} \mathrm{ppm}$, from $68.20 \pm 4.03$ to $90.83 \pm 5.34 \%$ at $5.0 \times 10^{4} \mathrm{ppm}$ and from $77.78 \pm 2.83$ to $92.26 \pm 4.50 \%$ at $10.0 \times 10^{4} \mathrm{ppm}$.

The repellent action of Mitracarpus hirtus leaf powder from 1 to 24 HAE varied for different concentrations. Repellency was from $47.50 \pm 4.79$ to $90.63 \pm 5.98 \%$ at $2.5 \times 10^{4}$ ppm, from $50.00 \pm 4.08$ to $92.26 \pm 4.50 \%$ at $5.0 \times 10^{4} \mathrm{ppm}$ and from $71.75 \pm 6.18$ to 93.30 $\pm 3.88 \%$ at $10.0 \times 10^{4} \mathrm{ppm}$ (Table 1 ).

Application of Senna obtusifolia at the three concentrations showed different repellency levels across the exposure periods: the recorded ranges were from $40.49 \pm 1.44$ to 63.54 $\pm 5.21 \%$ at $2.5 \times 10^{4} \mathrm{ppm}$, from $43.19 \pm 1.19$ to $72.09 \pm 3.29 \%$ at $5.0 \times 10^{4} \mathrm{ppm}$ and from $46.51 \pm 3.70$ to $77.50 \pm 3.69 \%$ at $10.0 \times 10^{4} \mathrm{ppm}$ (Table 1 ). 
Table 1. Mean repellency of botanical powders applied at different concentrations against Sitophilus zeamais within 24 hours. Conc. - concentration (x $10^{4} \mathrm{ppm}$ ).

\begin{tabular}{lccccc}
\hline \multicolumn{1}{c}{ Treatments } & Conc. & \multicolumn{4}{c}{ Mean Repellency (\% \pm S. E.) } \\
\cline { 2 - 5 } & & \multicolumn{4}{c}{ Exposure Period (HAE) } \\
\cline { 2 - 5 } & & $\mathbf{1}$ & $\mathbf{6}$ & $\mathbf{1 2}$ \\
\hline Euphorbia & 2.5 & $83.09 \pm 1.17^{\mathrm{a}}$ & $81.16 \pm 3.62^{\mathrm{ab}}$ & $80.32 \pm 1.87^{\mathrm{ab}}$ & $79.73 \pm 3.28^{\mathrm{ab}}$ \\
balsamifera & 5.0 & $86.67 \pm 4.51^{\mathrm{a}}$ & $83.93 \pm 3.01^{\mathrm{ab}}$ & $82.54 \pm 1.68^{\mathrm{ab}}$ & $81.01 \pm 2.32^{\mathrm{a}}$ \\
& 10.0 & $94.10 \pm 3.42^{\mathrm{a}}$ & $88.82 \pm 0.51^{\mathrm{a}}$ & $86.25 \pm 2.17^{\mathrm{a}}$ & $82.22 \pm 2.22^{\mathrm{a}}$ \\
Lawsonia & 2.5 & $80.42 \pm 7.08^{\mathrm{ab}}$ & $80.36 \pm 6.60^{\mathrm{ab}}$ & $72.36 \pm 2.49^{\mathrm{b}}$ & $63.34 \pm 1.93^{\mathrm{b}}$ \\
inermis & 5.0 & $90.83 \pm 5.34^{\mathrm{a}}$ & $84.29 \pm 6.00^{\mathrm{ab}}$ & $80.61 \pm 3.72^{\mathrm{ab}}$ & $68.20 \pm 4.03^{\mathrm{b}}$ \\
& 10.0 & $92.26 \pm 4.50^{\mathrm{a}}$ & $88.30 \pm 4.21^{\mathrm{a}}$ & $81.11 \pm 2.65^{\mathrm{ab}}$ & $77.78 \pm 2.83^{\mathrm{ab}}$ \\
Mitracarpus & 2.5 & $90.63 \pm 5.98^{\mathrm{a}}$ & $80.46 \pm 2.46^{\mathrm{ab}}$ & $79.07 \pm 2.31^{\mathrm{ab}}$ & $47.50 \pm 4.79^{\mathrm{c}}$ \\
hirtus & 5.0 & $92.26 \pm 4.50^{\mathrm{a}}$ & $86.71 \pm 4.73^{\mathrm{a}}$ & $79.62 \pm 2.27^{\mathrm{ab}}$ & $50.00 \pm 4.08^{\mathrm{c}}$ \\
Senna & 10.0 & $93.30 \pm 3.88^{\mathrm{a}}$ & $89.72 \pm 4.09^{\mathrm{a}}$ & $81.11 \pm 2.65^{\mathrm{ab}}$ & $71.75 \pm 6.18^{\mathrm{ab}}$ \\
obtusifolia & 2.5 & $63.54 \pm 5.21^{\mathrm{b}}$ & $61.18 \pm 2.33^{\mathrm{c}}$ & $55.63 \pm 4.00^{\mathrm{c}}$ & $40.49 \pm 1.44^{\mathrm{c}}$ \\
& 5.0 & $72.09 \pm 3.29^{\mathrm{ab}}$ & $67.38 \pm 2.71^{\mathrm{b}}$ & $63.68 \pm 3.11^{\mathrm{c}}$ & $43.19 \pm 1.19^{\mathrm{c}}$ \\
Permethrin & 10.0 & $77.50 \pm 3.69^{\mathrm{ab}}$ & $69.45 \pm 2.78^{\mathrm{b}}$ & $66.88 \pm 3.44^{\mathrm{bc}}$ & $46.51 \pm 3.70^{\mathrm{c}}$ \\
\hline Means in the same column followed by a different letter superscript are & 0.056 & $100.00 \pm 0.00^{\mathrm{a}}$ & $96.43 \pm 3.57^{\mathrm{a}}$ & $90.18 \pm 6.08^{\mathrm{a}}$ & $75.36 \pm 1.76^{\mathrm{b}}$ \\
by the Bonferrontly different at $p<0.05$ & & &
\end{tabular}

The permethrin powder applied at $0.056 \times 10^{4} \mathrm{ppm}$ showed complete $(100.00 \pm 0.00 \%)$ repellency against Sitophilus zeamais at the end of one HAE but decreased to 75.36 $\pm 1.76 \%$ at $24 \mathrm{HAE}$ (Table 1 ).

Table 1 shows that the repellency of the powders at concentrations 2.5, 5.0 and $10 \times 10^{4}$ ppm within $24 \mathrm{HAE}$ decreased in the order Euphorbia balsamifera $>$ Lawsonia inermis $>$ Permethrin > Mitracarpus hirtus > Senna obtusifolia.

At the end of $24 \mathrm{HAE}$, analysis of variance showed that the difference among the repellency levels of the botanical powders applied at varying concentrations was significant $(F(4,12)=63.49, p<0.001)$. Bonferroni's multiple comparisons test indicated that the percentage repellencies of Euphorbia balsamifera at 5.0 and $10.0 \times 10^{4} \mathrm{ppm}$ were the same and that both were higher than the other treatments within 24 hours. The multiple comparisons also showed that permethrin powder had the same repellency level as Lawsonia inermis at 5.0 and $10.0 \times 10^{4} \mathrm{ppm}$. 
SULEIMAN M. et al.: Repellency of botanicals against Sitophilus zeamais (Coleoptera) 91

\section{Repellency of methanolic extracts of the botanicals against Sitophilus zeamais}

The repellent activities of methanolic leaf extracts of the four plant species against $S$. zeamais varied within 24 hours of exposure. The results in Table 2 show that the repellency of Eubphorbia balsamifera varied between $70.42 \pm 4.43$ and $96.43 \pm 3.57 \%$ at $2.5 \times 10^{4}$ ppm, between $77.50 \pm 3.69$ and $100.00 \pm 0.00 \%$ at $5.0 \times 10^{4} \mathrm{ppm}$ and between $83.93 \pm 5.92$ and $100.00 \pm 0.00 \%$ at $10.0 \times 10^{4} \mathrm{ppm}$.

The repellency actions of $L$. inermis showed that an application rate of $2.5 \times 10^{4} \mathrm{ppm}$ repelled from $70.84 \pm 2.41$ to $96.88 \pm 3.13 \%$ weevils; the percentage repellency increased from $77.44 \pm 2.64$ to $100.00 \pm 0.00 \%$ at $5.0 \times 10^{4} \mathrm{ppm}$. At $10.0 \times 10^{4} \mathrm{ppm}$, Lawsonia inermis resulted in $91.67 \pm 4.81$ to $100.00 \pm 0.00 \%$ percentage repellency within 24 hours of exposure (Table 2).

Table 2. Mean repellency of methanolic botanical extracts applied at different concentrations against Sitophilus zeamais within 24 hours of exposure. Conc. concentration (x $\left.10^{4} \mathrm{ppm}\right)$.

\begin{tabular}{lccccc}
\hline \multirow{2}{*}{ Treatments } & Conc. & \multicolumn{4}{c}{ Mean Repellency (\% \pm S. E.) } \\
\cline { 3 - 5 } & & \multicolumn{4}{c}{ Exposure Period (HAE) } \\
\cline { 2 - 5 } & & $\mathbf{1}$ & $\mathbf{1 2}$ & $\mathbf{2 4}$ \\
\hline Euphorbia & 2.5 & $70.42 \pm 4.43^{\mathrm{b}}$ & $84.58 \pm 5.42^{\mathrm{ab}}$ & $91.67 \pm 4.81^{\mathrm{ab}}$ & $96.43 \pm 3.57^{\mathrm{a}}$ \\
balsamifera & 5.0 & $77.50 \pm 3.69^{\mathrm{ab}}$ & $88.09 \pm 4.01^{\mathrm{ab}}$ & $95.83 \pm 4.17^{\mathrm{ab}}$ & $100.00 \pm 0.00^{\mathrm{a}}$ \\
& 10.0 & $83.93 \pm 5.92^{\mathrm{ab}}$ & $92.86 \pm 4.13^{\mathrm{a}}$ & $100.00 \pm 0.00^{\mathrm{a}}$ & $100.00 \pm 0.00^{\mathrm{a}}$ \\
Lawsonia & 2.5 & $70.84 \pm 2.41^{\mathrm{b}}$ & $85.83 \pm 4.79^{\mathrm{ab}}$ & $95.83 \pm 4.17^{\mathrm{ab}}$ & $96.88 \pm 3.13^{\mathrm{a}}$ \\
inermis & 5.0 & $77.44 \pm 2.64^{\mathrm{ab}}$ & $88.69 \pm 6.97^{\mathrm{ab}}$ & $96.43 \pm 3.57^{\mathrm{ab}}$ & $100.00 \pm 0.00^{\mathrm{a}}$ \\
& 10.0 & $91.67 \pm 4.81^{\mathrm{a}}$ & $95.83 \pm 4.17^{\mathrm{a}}$ & $100.00 \pm 0.00^{\mathrm{a}}$ & $100.00 \pm 0.00^{\mathrm{a}}$ \\
Mitracarpus & 2.5 & $69.17 \pm 3.63^{\mathrm{b}}$ & $76.25 \pm 1.25^{\mathrm{b}}$ & $86.67 \pm 4.51^{\mathrm{ab}}$ & $92.26 \pm 4.50^{\mathrm{a}}$ \\
hirtus & 5.0 & $76.61 \pm 2.09^{\mathrm{ab}}$ & $77.50 \pm 1.44^{\mathrm{b}}$ & $91.43 \pm 5.09^{\mathrm{ab}}$ & $96.43 \pm 3.57^{\mathrm{a}}$ \\
Senna & 10.0 & $81.67 \pm 0.96^{\mathrm{ab}}$ & $87.50 \pm 4.17^{\mathrm{ab}}$ & $95.00 \pm 5.00^{\mathrm{ab}}$ & $100.00 \pm 0.00^{\mathrm{a}}$ \\
obtusifolia & 2.5 & $67.09 \pm 3.07^{\mathrm{b}}$ & $74.17 \pm 2.76^{\mathrm{b}}$ & $79.58 \pm 1.72^{\mathrm{b}}$ & $85.83 \pm 4.79^{\mathrm{a}}$ \\
& 5.0 & $74.53 \pm 3.31^{\mathrm{ab}}$ & $77.50 \pm 3.69^{\mathrm{b}}$ & $82.26 \pm 1.39^{\mathrm{b}}$ & $90.83 \pm 5.34^{\mathrm{a}}$ \\
\hline & 10.0 & $80.42 \pm 1.97^{\mathrm{ab}}$ & $85.83 \pm 4.79^{\mathrm{ab}}$ & $95.83 \pm 4.17^{\mathrm{ab}}$ & $100.00 \pm 0.00^{\mathrm{a}}$ \\
\hline
\end{tabular}

Means in the same column followed by a different letter superscript are significantly different at $p<0.05$ by the Bonferroni multiple comparisons test.

The use of Mitracarpus hirtus at $2.5 \times 10^{4} \mathrm{ppm}$ repelled $69.17 \pm 3.62,76.25 \pm 1.25$, $86.67 \pm 4.51$ and $92.26 \pm 4.50 \%$ weevils at $1,6,12$ and $24 \mathrm{HAE}$, respectively. At $5.0 \times 10^{4}$ ppm, the percentage repellencies recorded within 1, 6, 12 and $24 \mathrm{HAE}$ were $76.61 \pm 2.09$, 
$77.50 \pm 1.44,91.43 \pm 5.09$ and $96.43 \pm 3.57 \%$. Increasing the application rate to $10.0 \times 10^{4}$ ppm resulted in the repelling of from $81.67 \pm 0.96$ to $100.00 \pm 0.00 \%$ weevils within 24 HAE (Table 2).

The results presented in Table 2 show that the repellency levels of Senna obtusifolia varied within 24 HAE. Application of $2.5 \times 10^{4} \mathrm{ppm}$ of the botanical repelled from 67.09 \pm 3.07 to $85.83 \pm 4.79 \%$ weevils from 1 to $24 \mathrm{HAE}$. The percentage repellency of the botanical at the concentration of $5.0 \times 10^{4} \mathrm{ppm}$ varied between $74.53 \pm 3.31$ and 90.83 $\pm 5.34 \%$. The highest repellency was recorded at $10.0 \times 10^{4} \mathrm{ppm}$ of the botanical and ranged from $80.42 \pm 1.97$ to $100.00 \pm 0.00 \%$.

Analysis of variance showed that the repellency levels of methanolic extracts of the botanicals at different concentrations against Sitophilus zeamais within 24 hours of exposure were not significantly different $(F(3,9)=2.153, p=0.1636)$.

\section{Repellency of ethanolic extracts of the botanicals against Sitophilus zeamais}

Table 3 shows that Euphorbia balsamifera applied at $2.50 \times 10^{4} \mathrm{ppm}$ repelled 88.75 \pm 6.58 to $93.65 \pm 3.72 \%$ Sitophilus zeamais from 1 to 24 hours of treatment. Application of the botanical at $5.0 \times 10^{4} \mathrm{ppm}$ resulted in a percentage repellency of $90.83 \pm 5.34$ to 100.00 $\pm 0.00 \%$. This was slightly higher at $10.0 \times 10^{4} \mathrm{ppm}$ and recorded as $92.26 \pm 4.50100 .00$ $\pm 0.00 \%$ from 1 to 24 hours HAE.

As shown in Table 3, the percentage repellencies of Lawsonia inermis at a concentration of $2.5 \times 10^{4} \mathrm{ppm}$ against Sitophilus zeamais within 1, 6, 12 and $24 \mathrm{HAE}$ were $82.50 \pm 5.95$, $83.75 \pm 5.54,85.91 \pm 1.14$ and $87.05 \pm 0.45 \%$, respectively. At $5.0 \times 10^{4} \mathrm{ppm}$ of the botanical, the percentage repellency increased and varied between $85.83 \pm 4.79$ and 94.10 $\pm 3.42 \%$ within 24 HAE. The highest repellency was recorded in treatments of $10.0 \times 10^{4}$ ppm and ranged from $90.83 \pm 5.34$ to $97.50 \pm 2.50 \%$ to 24 HAE.

Mitracarpus hirtus repelled $77.50 \pm 1.44$ to $86.25 \pm 2.17 \%$ Sitophilus zeamais from 1 to $24 \mathrm{HAE}$ at $2.5 \times 10^{4} \mathrm{ppm}$. At $5.0 \times 10^{4} \mathrm{ppm}$, the botanical repelled from $79.58 \pm 1.72$ to $85.08 \pm 1.85 \%$ and at $10.0 \times 10^{4} \mathrm{ppm}$ the repellency was from $82.26 \pm 1.39$ to 90.00 $\pm 4.08 \%$ (Table 3 ).

The repellency of Senna obtusifolia followed the same pattern as that of the other botanicals, where it ranged from $80.42 \pm 7.08$ to $92.50 \pm 2.50 \%$ at $2.5 \times 10^{4} \mathrm{ppm}$, from $83.75 \pm 5.54$ to $93.93 \pm 3.61 \%$ at $5.0 \times 10^{4} \mathrm{ppm}$ and from $85.42 \pm 5.24$ to $100.00 \pm 0.00 \%$ at $10.0 \times 10^{4}$ ppm within $1,6,12$ and 24 HAE (Table 3 ).

The varying concentrations of ethanolic extracts showed different degrees of repellency against the maize weevils within 24 hours of exposure. At $2.5 \times 10^{4} \mathrm{ppm}$, Euphorbia balsamifera had the highest repellency, followed by Semma obtusifolia, Lawsonia inermis and Mitracarpus hirtus. At 5.0 and $10.0 \times 10^{4} \mathrm{ppm}$, the decreasing order of repellent action was Euphorbia balsamifera $>$ Lawsonia inermis $>$ Senna obtusifolia $>$ Mitracarpus hirtus. 
SULEIMAN M. et al.: Repellency of botanicals against Sitophilus zeamais (Coleoptera) 93

Table 3. Mean repellency of ethanolic botanical extracts applied at different concentrations against Sitophilus zeamais within 24 hours of exposure. Conc. - concentration (x $\left.10^{4} \mathrm{ppm}\right)$.

\begin{tabular}{lccccc}
\hline \multirow{2}{*}{ Treatments } & Conc. & \multicolumn{4}{c}{ Mean Repellency (\% \pm S. E.) } \\
\cline { 3 - 5 } & & \multicolumn{4}{c}{ Exposure Period (HAE) } \\
\cline { 2 - 5 } & & $\mathbf{1}$ & $\mathbf{6}$ & $\mathbf{1 2}$ & $\mathbf{2 4}$ \\
\hline Euphorbia & 2.5 & $88.75 \pm 6.58^{\mathrm{a}}$ & $88.75 \pm 6.58^{\mathrm{a}}$ & $91.67 \pm 4.81^{\mathrm{ab}}$ & $93.65 \pm 3.72^{\mathrm{ab}}$ \\
balsamifera & 5.0 & $90.83 \pm 5.34^{\mathrm{a}}$ & $92.26 \pm 4.50^{\mathrm{a}}$ & $100.00 \pm 0.00^{\mathrm{a}}$ & $100.00 \pm 0.00^{\mathrm{a}}$ \\
& 10.0 & $92.26 \pm 4.50^{\mathrm{a}}$ & $96.43 \pm 3.57^{\mathrm{a}}$ & $100.00 \pm 0.00^{\mathrm{a}}$ & $100.00 \pm 0.00^{\mathrm{a}}$ \\
Lawsonia & 2.5 & $82.50 \pm 5.95^{\mathrm{a}}$ & $83.75 \pm 5.54^{\mathrm{a}}$ & $85.91 \pm 1.14^{\mathrm{b}}$ & $87.05 \pm 0.45^{\mathrm{b}}$ \\
inermis & 5.0 & $85.83 \pm 4.79^{\mathrm{a}}$ & $90.83 \pm 5.34^{\mathrm{a}}$ & $91.32 \pm 2.91^{\mathrm{ab}}$ & $94.10 \pm 3.42^{\mathrm{b}}$ \\
& 10.0 & $90.83 \pm 5.34^{\mathrm{a}}$ & $92.22 \pm 4.84^{\mathrm{a}}$ & $95.00 \pm 2.89^{\mathrm{a}}$ & $97.50 \pm 2.50^{\mathrm{a}}$ \\
Mitracarpus & 2.5 & $77.50 \pm 1.44^{\mathrm{a}}$ & $81.25 \pm 6.25^{\mathrm{a}}$ & $84.73 \pm 1.63^{\mathrm{b}}$ & $86.25 \pm 2.17^{\mathrm{b}}$ \\
hirtus & 5.0 & $79.58 \pm 1.72^{\mathrm{a}}$ & $82.86 \pm 1.65^{\mathrm{a}}$ & $85.08 \pm 1.85^{\mathrm{b}}$ & $87.22 \pm 2.42^{\mathrm{b}}$ \\
& 10.0 & $82.26 \pm 1.39^{\mathrm{a}}$ & $85.32 \pm 1.32^{\mathrm{a}}$ & $87.68 \pm 0.88^{\mathrm{ab}}$ & $90.00 \pm 4.08^{\mathrm{ab}}$ \\
Senna & 2.5 & $80.42 \pm 7.08^{\mathrm{a}}$ & $83.75 \pm 5.54^{\mathrm{a}}$ & $86.67 \pm 4.51^{\mathrm{ab}}$ & $92.50 \pm 2.50^{\mathrm{ab}}$ \\
obtusifolia & 5.0 & $83.75 \pm 5.54^{\mathrm{a}}$ & $86.67 \pm 4.51^{\mathrm{a}}$ & $92.26 \pm 4.50^{\mathrm{ab}}$ & $93.93 \pm 3.61^{\mathrm{ab}}$ \\
& 10.0 & $85.42 \pm 5.24^{\mathrm{a}}$ & $90.83 \pm 5.34^{\mathrm{a}}$ & $95.83 \pm 4.17^{\mathrm{a}}$ & $100.00 \pm 0.00^{\mathrm{a}}$ \\
\hline
\end{tabular}

Means in the same column followed by a different letter superscript are significantly different at $p<0.05$ by the Bonferroni multiple comparisons test.

Two-way ANOVA showed that the difference in repellency levels among ethanolic extracts of the botanicals at the three concentrations $-2.5,5.0$ and $10.0 \times 10^{4} \mathrm{ppm}-$ was highly significant $(F(3,9)=7.268, p<0.0001)$ within 24 hours.

Mean separation by the Bonferroni multiple comparisons test indicated that at $5.0 \times 10^{4}$ ppm, the percentage repellency of E. balsamifera was statistically higher than those of Lawsonia inermis, Mitracarpus hirtus and Senna obtusifolia, while those of Lawsonia inermis and Mitracarpus hirtus were the same within 24 HAE. However, at $2.5 \times 10^{4} \mathrm{ppm}$, the mean percentage repellencies of Euphorbia balsamifera and Senna obtusifolia were the same and were both higher than those of Lawsonia inermis and Mitracarpus hirtus after 24 hours of exposure (Table 3 ).

\section{Repellency of aqueous extracts of the botanicals against Sitophilus zeamais}

The percentage repellency of Euphorbia balsamifera decreased across the exposure periods and ranged from $48.89 \pm 3.96$ to $68.90 \pm 2.73 \%$ at $2.5 \times 10^{4} \mathrm{ppm}$, from $56.95 \pm 3.50$ to $75.95 \pm 9.29 \%$ at $5.0 \times 10^{4} \mathrm{ppm}$, and from $60.14 \pm 1.64$ to $81.61 \pm 6.38 \%$ at $10.0 \times 10^{4}$ ppm within $24 \mathrm{HAE}$ (Table 4). 
Table 4. Mean repellency of aqueous botanical extracts applied at different concentrations against Sitophilus zeamais within 24 hours of exposure. Conc. - concentration (x $\left.10^{4} \mathrm{ppm}\right)$.

\begin{tabular}{lccccc}
\hline \multirow{2}{*}{ Treatments } & Conc. & \multicolumn{4}{c}{ Mean Repellency (\% \pm S. E.) } \\
\cline { 3 - 5 } & & \multicolumn{4}{c}{ Exposure Period (HAE) } \\
\cline { 2 - 5 } & & $\mathbf{1}$ & $\mathbf{6}$ & $\mathbf{1 2}$ \\
\hline Euphorbia & 2.5 & $68.90 \pm 2.73^{\mathrm{a}}$ & $65.63 \pm 1.04^{\mathrm{a}}$ & $58.41 \pm 1.72^{\mathrm{a}}$ & $48.89 \pm 3.96^{\mathrm{a}}$ \\
balsamifera & 5.0 & $75.95 \pm 9.29^{\mathrm{a}}$ & $67.23 \pm 3.57^{\mathrm{a}}$ & $62.29 \pm 1.57^{\mathrm{a}}$ & $56.95 \pm 3.50^{\mathrm{a}}$ \\
& 10.0 & $81.61 \pm 6.38^{\mathrm{a}}$ & $73.75 \pm 1.25^{\mathrm{a}}$ & $68.75 \pm 3.15^{\mathrm{a}}$ & $60.14 \pm 1.64^{\mathrm{a}}$ \\
Lawsonia & 2.5 & $65.36 \pm 6.56^{\mathrm{a}}$ & $61.58 \pm 2.02^{\mathrm{a}}$ & $55.91 \pm 2.56^{\mathrm{a}}$ & $45.49 \pm 2.97^{\mathrm{a}}$ \\
inermis & 5.0 & $72.92 \pm 9.08^{\mathrm{a}}$ & $63.69 \pm 4.70^{\mathrm{a}}$ & $56.18 \pm 5.86^{\mathrm{a}}$ & $47.27 \pm 4.17^{\mathrm{a}}$ \\
& 10.0 & $80.95 \pm 7.23^{\mathrm{a}}$ & $71.88 \pm 4.62^{\mathrm{a}}$ & $61.81 \pm 5.60^{\mathrm{a}}$ & $58.05 \pm 9.19^{\mathrm{a}}$ \\
Mitracarpus & 2.5 & $63.54 \pm 5.21^{\mathrm{a}}$ & $56.34 \pm 4.53^{\mathrm{a}}$ & $50.40 \pm 2.60^{\mathrm{a}}$ & $45.77 \pm 4.24^{\mathrm{a}}$ \\
hirtus & 5.0 & $72.29 \pm 9.34^{\mathrm{a}}$ & $63.81 \pm 3.23^{\mathrm{a}}$ & $58.73 \pm 2.67^{\mathrm{a}}$ & $52.78 \pm 4.81^{\mathrm{a}}$ \\
Senna & 10.0 & $80.21 \pm 7.86^{\mathrm{a}}$ & $65.03 \pm 6.23^{\mathrm{a}}$ & $59.03 \pm 2.00^{\mathrm{a}}$ & $54.52 \pm 5.05^{\mathrm{a}}$ \\
obtusifolia & 2.5 & $59.70 \pm 7.51^{\mathrm{a}}$ & $54.91 \pm 5.09^{\mathrm{a}}$ & $48.61 \pm 5.26^{\mathrm{a}}$ & $41.37 \pm 7.39^{\mathrm{a}}$ \\
& 5.0 & $65.42 \pm 8.91^{\mathrm{a}}$ & $60.15 \pm 6.96^{\mathrm{a}}$ & $55.68 \pm 2.10^{\mathrm{a}}$ & $50.72 \pm 3.52^{\mathrm{a}}$ \\
& 10.0 & $75.95 \pm 6.32^{\mathrm{a}}$ & $70.12 \pm 6.73^{\mathrm{a}}$ & $62.30 \pm 9.11^{\mathrm{a}}$ & $56.39 \pm 4.72^{\mathrm{a}}$ \\
\hline
\end{tabular}

Means in the same column followed by a different letter superscript are significantly different at $p<0.05$ by the Bonferroni multiple comparisons test.

Table 4 shows that the percentage repellency of Lawsonia inermis at $2.5 \times 10^{4} \mathrm{ppm}$ was $65.36 \pm 6.56,61.58 \pm 2.02,55.91 \pm 2.56$ and $45.49 \pm 2.97 \%$ within $1,6,12$ and 24 HAE. Application of the botanical at $5.0 \times 10^{4} \mathrm{ppm}$ repelled $47.27 \pm 4.17$ to $72.92 \pm 9.08 \%$ of the insects. At a concentration of $10.0 \times 10^{4} \mathrm{ppm}$, the botanical had a percentage repellency of $80.95 \pm 7.23,71.88 \pm 4.62,61.81 \pm 5.60$ and $58.05 \pm 9.19$ within $1,6,12$ and 24 HAE.

The percentage repellency of Mitracarpus hirtus at an application rate of $2.5 \times 10^{4} \mathrm{ppm}$ ranged from $45.77 \pm 4.24$ to $63.54 \pm 5.21$ from 1 to 24 hours (Table 4). Increasing the concentration to $5.0 \times 10^{4} \mathrm{ppm}$ resulted in repellency varying between $52.78 \pm 4.81$ and $72.29 \pm 9.34 \%$. At $10.0 \times 10^{4} \mathrm{ppm}$ of the botanical, the percentage repellency ranged from $54.52 \pm 5.05$ to $80.21 \pm 7.86 \%$ from 1 to 24 hours of exposure (Table 4).

Table 4 shows that application of Senna obtusifolia resulted in repelling from 41.37 \pm 7.39 to $59.70 \pm 7.51 \%$ Sitophilus zeamais at $2.5 \times 10^{4} \mathrm{ppm}$ and from $50.72 \pm 3.52$ to $65.42 \pm 8.91 \%$ at $5.0 \times 10^{4} \mathrm{ppm}$ from 1 to 24 hours. At $10.0 \times 10^{4} \mathrm{ppm}$ of the botanical, the percentage repellency recorded within one hour was $75.95 \pm 6.32 \%$, which decreased to $70.12 \pm 6.73,62.30 \pm 9.11$ and $56.39 \pm 4.72 \%$ within 6,12 and $24 \mathrm{HAE}$. 
The repellency levels of aqueous extracts of the botanicals decreased in the following order: Euphorbia balsamifera > Mitracarpus hirtus > Lawsonia inermis > Senna obtusifolia.

Analysis of variance showed that the percentage repellencies of aqueous extracts of the botanicals at concentrations of 2.5, 5.0 and $10.0 \times 10^{4} \mathrm{ppm}$ against Sitophilus zeamais after 24 hours of treatments were not significantly different $(F(3,9)=0.4635, p=0.7148)$.

\section{DISCUSSION}

All the botanicals - Euphorbia balsamifera, Lawsonia inermis, Mitracarpus hirtus and Senna obtusifolia - exhibited repellent potential against adult Sitophilus zeamais in stored sorghum. The repellent activity of Euphorbia balsamifera and Lawsonia inermis leaf powders against Sitophilus zeamais was confirmed by SULEIMAN et al. (2012), who found that $0.3 \mathrm{~g}$ of leaf powders of Euphorbia balsamifera and Lawsonia inermis repelled adult Sitophilus zeamais after 3 hours of exposure. The findings of this study confirmed the repellency potential of some botanical powders against $S$. zeamais. PARUGRUG \& ROXAS (2008) recorded the highest (7.00) repellency of Azadirachta indica against Sitophilus zeamais after 1 hour of exposure. MWANGANGI \& MUTSIYA (2013) reported that basil powder was capable of repelling S. zeamais weevils to a distance of $6.60 \mathrm{~cm}$ within the first two hours of exposure. The trend of decreasing repellency of botanical powders with increasing exposure periods is in agreement with PARUGRUG \& ROXAS (2008), who reported a decrease in the repellency of Azadirachta indica against Sitophilus zeamais from 7.00 after 1 hour to 3.53 after 96 hours. They also reported a decrease in the repellency rating of Tagetes erecta L. from 6.90 to 1.13 after 96 hours of exposure.

Methanolic extracts were strongly repellent against Sitophilus zeamais, in which the repellent effect of Euphorbia balsamifera, Lawsonia inermis and Mitracarpus hirtus was higher than that of Senna obtusifolia; the highest was by Lawsonia inermis. Although information is scanty on the repellent actions of methanolic extracts of these botanicals, repellent activities of methanolic extracts of other botanicals against Sitophilus zeamais and related species elsewhere have been reported. WeKESA et al. (2011) recorded 35\% repellency of a methanolic extract of Hyptis spicigera LAM. against Sitophilus zeamais when applied at $100 \mathrm{mg} / 20 \mathrm{~g}$ maize grains. Methanolic extracts of Curcuma longa L. and Kaempferia pulchra RIDL. rhizomes applied at $1.415 \mu \mathrm{g} / \mathrm{cm}^{2}$ repelled $86.0 \%$ and $76 \%$ Sitophilus zeamais, respectively, at 8 hours after treatment (ARYANI \& AUAMCHAROEN, 2016). Another work by GIDEON et al. (2016) revealed that methanolic extracts of Securidaca longepedunculata FRESEN applied at $0.10 \mathrm{~g} / \mathrm{ml}$ repelled $60.27 \%$ of Sitophilus zeamais after 30 minutes of exposure. The findings of KARAKAS (2016) indicated the 
effectiveness of methanolic extracts of dill and basil leaves in repelling adult Sitophilus granarius (LINNAEUS, 1758) in wheat: this was above 50\% at the end of a 5-hour observation period. These findings concur with those obtained in the present study.

The present study demonstrated for the first time that ethanolic extracts of Euphorbia balsamifera, Lawsonia inermis, Mitracarpus hirtus and Senna obtusifolia had repellency potential against Sitophilus zeamais. AKINBULUMA et al. (2015) reported similar observations that ethanolic extracts of Capsicum frutescens L. and Dennettia tripetala BAKER f. had repellent effects against Sitophilus zeamais and recorded 91.68 and 89.58\% repellency of Capsicum frutescens and Dennettia tripetala, respectively. Similarly, VIGLIANCO et al. (2008) reported that ethanolic extracts of Solanum argentinum BITTER et LILLO repelled 55.0\% of Sitophilus oryzae (LINNAEUS, 1763).

Aqueous extracts of all four selected botanicals were also found to be repellent against Sitophilus zeamais, even though the degree of repellency was lower than that of the powders, methanolic and ethanolic extracts used in this study. Euphorbia balsamifera remained the top botanical in repelling adult Sitophilus zeamais in aqueous extract formulations. DE OlIVEIRA et al. (2012) stated that an aqueous leaf extract of Eschweilera pedicellata (RICH.) S.A. MORI applied at $1 \mathrm{mg} / \mathrm{ml}$ concentration was repellent against Sitophilus zeamais after 2 hours of treatment. KARAKAS (2016) showed that aqueous extracts of dill and purple basil leaves elicited 41.38 and $38.58 \%$ repellency of Sitophilus granarius respectively. The repellent activity of aqueous extracts of the botanicals selected for this study agrees with the findings of PADIN et al. (2013) that aqueous extracts of nine botanicals invoked repellency of Tribolium castaneum (HERBST, 1797).

All the selected botanicals were found to demonstrate repellent activity against adult Sitophilus zeamais in stored sorghum, which could probably reduce grain attack by the weevils. The study also demonstrated that Euphorbia balsamifera and Lawsonia inermis were generally more repellent against the weevils than the other plants and exhibited a repellent effect against the weevils similar to that of permethrin.

The repellent activities of the selected botanicals could be due to the presence of nonhost volatile odour components of plants that repelled insects (KUHNS et al. 2016). Active ingredients, such as alkaloids, flavonoids, saponins, phenolics and tannins, have been identified in Euphorbia balsamifera, Lawsonia inermis and Senna obtusifolia (DOUGHARI et al. 2008, KAMBA \& HASSAN 2010, RAJA et al. 2013). The bioactive compounds were found to confuse the insects' olfactory receptors so that they were unable to perceive the host odour (EFFIOM et al. 2012). It has been suggested that the toxic secondary metabolites present in extracts of botanicals such as Bridelia micrantha (HOCHST.) BAILL., Chasmanthera dependens HOCHST. and Vernonia cinerea (L.) LESS. were responsible for repellent action against the insect pest Dysdercus superstitious (HERRICH-SCHÄFFER, 1842) (ADESINA et al. 2016). 


\section{CONCLUSION}

The leaves of Euphorbia balsamifera, Lawsonia inermis, Mitrocarpus hirtus and Senna obtusifolia formulated as powders, methanolic, ethanolic or aqueous extracts displayed repellency potential against Sitophilus zeamais in stored sorghum. The repellency of Euphorbia balsamifera was similar to that of permethrin powder and was found to be stronger than that of the other botanicals; Senna obtusifolia was the least repellent, even though the degree of repellency was $>50 \%$. It was generally observed that the repellent actions of the selected botanicals were concentration-dependent: repellency increased with increasing concentration. Prolongation of exposure periods decreased the repellent actions of the botanical powders and aqueous extracts. In treatments with methanolic and ethanolic extracts, however, repellency rates were generally found to rise with increasing exposure time, showing their persistency up to the end of 24 HAE. It is therefore concluded that Euphorbia balsamifera, Lawsonia inermis, Mitrocarpus hirtus and Senna obtusifolia could be used as repellents against Sitophilus zeamais and could serve as protectants of stored sorghum seeds. Grains protected with these botanicals could be used as seeds for planting. Meanwhile, studies on the toxicity of these botanicals against higher animals are recommended.

\section{REFERENCES}

Abou-Elnaga Z.S. 2015. Efficacy of extracts of some Egyptian plants against economically important stored grains pest Sitophilus oryzae L. Journal of Entomology and Zoology Studies 3(1): 87-91.

AdESINA J.M., OfUYA T.I., RAJASHEKAR Y. 2016. Efficacy of some aqueous plant extracts against cotton stainers, Dysdercus superstitious (HERRICH SCHAFFER) (Hemiptera: Pyrrhocoridae). Journal of Entomology and Zoology Studies 4(4): 170-174.

Akinbuluma M.D., AdePetun M.T., YeYe E.O. 2015. Insecticidal effects of ethanol extracts of Capsicum frutescens and Dennettia tripetala against Sitophilus zeamais MOTSCHULSKY on stored maize. International Journal of Research in Agriculture and Forestry 2(11): 1-7.

ANKUTSE D.K. 2014. Bioactivities of six indigenous Ghanaian plants in managing Sitophilus zeamais and Prostephanus truncatus in stored maize in Volta Region. M.Phil. Th., University of Ghana, Legon.

Aryani D.S., Auamcharoen W. 2016. Repellency and contact toxicity of crude extracts from Thai plants (Zingiberaceae) against maize grain weevil, Sitophilus zeamais Motschulsky (Coleoptera: Curculionidae). Journal of Biopesticides 9(1): 52-62.

Asawalam E.F., Emosairue S.O. 2006. Comparative efficacy of Piper guineense (Schum and THONN) and Pirimiphos methyl as poison against Sitophilus zeamais (MоTSCH.). Electronic Journal of Environment, Agriculture and Food Chemistry 5(5): 1536-1545. 
DALES M.J. 1996. A review of plant materials used for controlling insect pests of stored products. NRI Bulletin 65 [Working paper]

De Oliveira T.A., Ronche-Teles B., Da Fonseca C.R.V., Da Silva S.L.R., Santos P.A., Nunez C.V. 2012. Insecticidal activity of Vitex cymosa (Lamiaceae) and Eschwelera pedicellata (Lecythidaceae) extracts against Sitophilus zeamais adults (Coleoptera: Curculionidae) Emirates Journal of Food and Agriculture 24(1): 49-56.

Doughari J.H., El-Mahmood A.M., Tyoyina I. 2008. Antimicrobial activity of leaf extracts of Senna obtusifolia (L.). African Journal of Pharmacy and Pharmacology 2(1): 7-13.

EFFiom O.E., AvoAJA D.A., OHAERI C.C. 2012. Mosquito repellent activity of phytochemical extracts from peels of Citrus fruit species. Global Journal of Science Frontier Research Interdisciplinary 12(1): 4-8.

GideOn E.N., QUARshiE A.A., Yeboah A.G. 2016. Biological activity of $S$. longepeduncula against $S$. zeamais and C. maculatus. Advances in Agriculture and Agricultural Sciences 2(2): 33-41.

Goftishu M., BelETE K. 2014. Susceptibility of sorghum varieties to the maize weevil Sitophilus zeamais MotsChULSKY (Coleoptera: Curculionidae). African Journal of Agricultural Research 9(31): 2419-2426.

Govindarajan M., Mathivanan T., Elumalai K., Krishnappa K., Anandan A. 2011. Ovicidal and repellent activities of botanical extracts against Culex quinquefasciatus, Aedes aegypti and Anopheles stephensi (Diptera: Culicidae). Asian Pacific Journal of Tropical Biomedicine 1(1): 43-48.

Jayanthi P.D.K., Kempraj V., Aurade R.M., Venkataramanappa R.K., Nandagopal B., VERGHESE A., BRUCE T.J.A. 2014. Specific volatile compounds from mango elicit oviposition in Gravid Bactrocera dorsalis females. Journal of Chemical Ecology 40(3): 529-566

KAMBA A.S., HASSAN L.G. 2010. Phytochemical screening and antimicrobial activities of Euphorbia balsamifera leaves, stems and root against some pathogenic microorganisms. African Journal of Pharmacy and Pharmacology 4(9): 645-652.

KARAKAS M. 2016. Toxic, repellent and antifeedant effects of two aromatic plant extracts on the wheat granary weevil, Sitophilus granarius L. (Coleoptera: Curculionidae). International Journal of Entomology Research 1(6): 24-28.

KhaliQ A., Nawas A., Ahmad N.H., Sagheer M. 2014. Assessment of insecticidal potential of medicinal plant extracts for control of maize weevil, Sitophilus zeamais MoTSCHULSKY (Coleoptera: Curculionidae). Basic Research Journal of Agricultural Science and Review 3(11): $100-104$.

Kunns E.H., Martini X., Hoyte A., Stelinski L.L. 2016. Repellent activity of botanical oils against Asian Citrus Psyllid, Diaphorina citri (Hemiptera: Liviidae). Insects 7(35): 1-13.

LALE N.S.E. 2006. Dictionary of Entomology and Acarology, $2^{\text {nd }}$ Ed. Mole Publications (Nig.) Ltd., Port Harcourt, Nigeria.

MaIA M.F., Moore S.J. 2011. Plant-based insect repellents: A review of their efficacy, development and testing. Malaria Journal 10(Suppl. 1): 1-14.

Mutambuki M., Ngatia C.M. 2012. Assessment of grain damage and weight loss on farmstored maize in highlands areas of Bungoma District, Kenya. Journal Agricultural Science and Technology B 2: 349-361. 
Mwangangi B.M., Mutisya D.L. 2013. Performance of basil powder as insecticide against maize weevil, Sitophilus zeamais (Coleoptera: Curculionidae). Discourse Journal of Agriculture and Food Sciences 1(11): 196-201.

Obico J.J.A., Ragragio E.M. 2014. A survey of plants used as repellents against hematophagous insects by the Ayta people of Porac, Pampanga province, Philippines. Philippine Science Letters 7(1): 179-186.

Padin S.B., Fuse C., UrRutia M.I., Bello G.M.D. 2013. Toxicity and repellency of nine medicinal plants against Tribolium castaneum in stored wheat. Bulletin of Insectology 66(1): 45-49.

PARUgrug A.M., RoXAs C. 2008. Insecticidal action of five plants against maize weevil, Sitophilus zeamais Motsch. (Coleoptera: Curculionidae). KMITL Science and Technology Journal 8(1): 24-38.

RAJA W., Ovais M., DubEY A. 2013. Phytochemical screening and antibacterial activity of Lawsonia inermis leaf extracts. International Journal of Microbiological Research 4(1): 33-36.

RAJASHEKAR Y., BAKTHAVATSAlAM N., ShivANANDAPPA T. 2012. Botanicals as grain protectants. Psyche 2012: 1-13.

Rejitha T.P., Reshma J.K., MAthew A. 2014. Study of repellent activity of different plant powders against cockroach (Periplanata americana). International Journal of Pure and Applied Bioscience 2(6): 185-194.

SAKUma M., FunKami H. 1985. The linear track olfactometer: an assay device for taxes of the German cockroach, Blatella germanica (LiNN.) towards their aggregation pheromone. Applied Entomology and Zoology 74(6): 523-525.

Suleiman M., Ibrahim N.D., MajeEd Q., AbubaKar U. 2012. Repellency potential of some plant powders against Sitophilus zeamais MotsChULSKY (Coleoptera: Curculionidae). Biological and Environmental Sciences Journal for the Tropics 9(2): 72-76.

TALUKDER F.A. 2006. Plant products as potential stored-product insect management agents - A mini review. Emirate Journal of Agricultural Science 18(1): 17-32.

Verma S., Sharma S., Malik A. 2016. Termiticidal and repellency efficacy of botanicals against Odontotermes obesus. International Journal of Research in Biosciences 5(2): 52-59.

Viglianco A.I., Novo R.J., Cragnolini C.I., Nassetta M., Cavallo E.A. 2008. Antifeedant and repellent effects of extracts of three plants from Cordoba (Argentina) Against Sitophilus oryzae (L.) (Coleoptera: Curculionidae). BioAssay 3(4): 1-6.

Wekesa I., Onek L.A., Deng A.L., Hasanali A., OthiRa J.O. 2011. Toxicity and repellent potency of Hyptis spicigera extracts on Sitophilus zeamais MoTSCHULSKY (Coleoptera: Curculionidae). Journal of Stored Products and Postharvest Research 2(6): 113-119.

ZoubiRi S., BAALIOUAMER A. 2014. Potentiality of plants as source of insecticide principles. Journal of Saudi Chemical Society 18(6): 925-938.

Received: 30 October 2017

Accepted: 27 December 2017 